\title{
REFORMULASI KONSTRUKSI PIDANA DALAM MENJERAT PELAKU TINDAK PIDANA KORPORASI
}

\author{
Yatini \\ Email: tinyatini09@gmail.com \\ Mahasiswa Pascasarjana Fakultas Hukum UNS Surakarta \\ Hari Purwadi \\ Email: Hpurwadie@gmail.com \\ Hartiwiningsih \\ Email: hartiwi50@yahoo.com \\ Dosen Fakultas Hukum Universitas Sebelas Maret
}

\begin{abstract}
This article aims to analyze the reformulation of corporate criminal responsibility in Indonesia by reviewing the legislation and court rulings as a reference, in a corporate crime not yet the custom of the public prosecutor or court to explore aspects of corporate crime and or ensnare the intellectual perpetrator in corporate crime, in the principle of a criminal act involving a corporation of criminal prosecution can be done, but it is almost never done, so that the process of law enforcement in a corporate crime is committed by committing a general crime, even though the crime of the company is a special crime which must also be dealt with in a special way. The results of this study have not implemented the concept of corporate crime by law enforcement, so that the perpetrators of the corporation avoid the deterrent effect, especially the perpetrators of intellectuals and corporations. This study uses the normative method by reviewing the Law with the help of secondary legal materials in the form of court decisions and other legal doctrines, using deductive and prescriptive analysis. The results show that law enforcers have not been able to enforce the law in relation to criminal offenses involving corporations, corporations that should be trapped with corporate crime are rarely snared because of incomprehension of public prosecutors in the construction of criminal law theory in corporate criminal concepts which has become prevalent in many countries today in both common law and civil law countries.
\end{abstract}

Keywords: Reformulation; Criminal liability; Corporations.

\begin{abstract}
Abstrak
Artikel ini bertujuan menganalisis reformulasi pertanggungjawaban pidana perusahaan di Indonesia dengan meninjau kembali aturan Perundang-undangan dan Putusan pengadilan sebagai acuan, dalam tindak pidana korporasi belum menjadi kebiasaan jaksa penuntut umum atau pengadilan untuk mengeksplorasi aspek kejahatan perusahaan dan atau menjerat pelaku intelektual dalam kejahatan korporasi, meski dalam prinsip tindak pidana yang melibatkan korporasi penindakan secara pidana dapat dilakukan, namun hampir tidak pernah dilakukan, sehingga proses penegakan hukum dalam tindak pidana korporasi dilakukan dengan melakukan tindak pidana umum, walaupun kejahatan perusahaan adalah kejahatan khusus yang mana juga harus ditangani dengan cara yang khusus. Hasil penelitian ini belum diimplementasikan konsep kejahatan korporasi yang benar oleh penegakan hukum, sehingga para pelaku korporasi terhindar dari efek jera, terutama pelaku intelektual dan korporasinya. Penelitian ini memakai
\end{abstract}


metode normatif dengan mengkaji Undang-undang dengan dibantu bahan-bahan hukum sekunder berupa putusan-putusan pengadilan dan doktrin-doktrin hukum lainnya, dengan memakai analisis deduktif dan preskriptif. Hasil penelitian menunjukkan bahwa para penegak hukum belum mampu dalam menegakkan hukum dalam kaitannya yang mengenai tindak pidana yang melibatkan korporasi, korporasi yang seharusnya dapat di jerat dengan tindak pidana korporasi jarang sekali di jerat karena ketidakpahaman jaksa penuntut umum dalam konstruksi teori hukum pidana dalam konsep pidana korporasi yang telah menjadi kelaziman di berbagai negara saat ini baik di negara dengan sistem common law maupun civil law.

Kata Kunci: Reformulasi; Pertanggungjawabanpidana; Korporasi.

\section{A. Pendahuluan}

Penulisan ini mencoba membahas kejahatan korporasi dalam kaitannya bagaimana konstruksi hukum yang membedakan antara konstruksi tindak pidana yang dilakukan korporasi dan tindak pidana yang dilakukan oleh perorangan dalam berbagai kasus tindak pidana yang seharusnya dapat menjerat korporasi dalam kerusakan dan kerugian secara massif yang telah ditimbulkan oleh korporasi yang biasanya melalui suruhan atau menyuruh orang lain atau sekelompok orang untuk melakukan tindak pidana yang massif dalam efek kerusakannya, sebagai contoh adalah dalam perkara perusakan hutan dan pencurian ikan di wilayah indonesia yang kaya hasil hutan dan hasil laut.

Indonesia adalah negara kepulauan yang terdiri atas 18.108 pulau dengan banyak diantara pulaunya belum terjamah dan belum mempunyai nama, bagian negara yang sangat luas ini merupakan aset nasional jangka panjang yang mengandung potensi sumber daya alam, untuk sebesar-besar kemakmuran rakyat, sesuai dengan amanat Undang-undang dasar 1945, dalam hal ini sumber daya alam tersebut adalah hutan dan ikan serta lingkungan hidup yang terjaga.(Muh Fityatul Kahfi. 2016:1)

Hal-hal tersebut diatas menunjukkan lemahnya penegakan hukum didalam urusan pidana korporasi maupun pidana lainnya yang seharusnya dapat memidanakan otak dari semua pelaku kejahatan massif tersebut yaitu korporasinya yang menyuruh melakukan dan melakukan pendanaan terhadap terjadinya tindak pidana tersebut.

Pertanggungjawaban pidana korporasi merupakan hal yang sangat berperan dalam kerangka kebijakan sosial. Kebijakan sosial (social policy) mencakup upaya kesejahteraan sosial (sosial welfare policy) dan perlindungan masyarakat (social defence policy). (Barda Nawawi Arief.2007:78-79) Untuk membantu kebijakan tersebut, criminal policy yang menggunakan sarana hukum pidana (penal policy) harus memenuhi unsur: kebijakan legislatif (tahap formulasi), kebijakan yudikatif (tahap aplikasi), dan kebijakan eksekutif (tahap eksekusi, yaitu tahap pelaksanaan hukum pidana). (Teguh Soedarsono. 2010:63) Kebijakan legislasi merupakan tahap paling strategis dari penal policy karena kelemahan kebijakan legislasi dapat menghambat upaya penanggulangan kejahatan pada tahap aplikasi dan eksekusi.(Barda Nawawi Arief dalam Mudzakkir.2010:11)Kebijakan legislasi mencakup upaya memberantas dan menanggulangi kejahatan dalam rangka social defence.(Yesmil Anwar dan Adang. 2008:21) Upaya ini harus dilandasi nilai-nilai kehidupan kebangsaan yaitu Pancasila dan UUD 1945 serta sesuai dengan tuntutan zaman (reformasi hukum). 
Formulasi pertanggungjawaban pidana korporasi merupakan langkah awal instrumen hukum pidana dalam menanggulangi tindak pidana yang melibatkan korporasi. Efektifitas yang mengandung arti "keefektifan (effectiveness) atau kemujaraban" dari kebijakan ini tidak terlepas dari dua karakteristik variabel, yaitu karakteristik "objek atau sasaran yang dituju" dan "sarana yang digunakan" (perangkat hukum pidana).Sistem pertanggungjawaban pidana korporasi sebagai bagian dari proses pemidanaan pada hakikatnya berpijak pada pemikiran tujuan dipidananya korporasi, sanksi apa yang diancamkan dan dijatuhkan serta bagaimana model pengaturannya.

Teori tujuan pemidanaan selalu mengikuti perkembangan kejahatan korporasi. Menurut Mahrus Ali, tujuan pemidanaan yang relevan bagi korporasi adalah teori deterrence (teori pencegahan) dan teori rehabilitasi.(Mahrus Ali. 2013: 264)Secara teoritis asumsi dasar teori deterrence bahwa setiap aktivitas korporasi bertujuan untuk memaksimalkan keuntungan (maximizing the expected utility) dan selalu ada motif ekonomi (orientasi untung rugi) dengan mempertimbangkan cost and benefit. Rasionalitas ekonomi inilah yang menjadi dasar penjatuhan pidana bagi korporasi.

Sebagai contoh Putusan Pengadilan tidak pernah memidanakan korporasi/perusahaannya, melainkan hanya orang-orang yang menjadi karyawan atau pelaku lapangan, sebab jaksa penuntut umum juga tidak pernah menggunakan konsep pidana korporasi dalam memidanakan pelaku yang sesungguhnya sebagai pelaku yang menyuruh atau otak suatu kejahatan yang menimbulkan efek yang jauh lebih besar dibanding para pelaku lapangan yang cenderung orang bayaran yang tidak berpendidikan atau berpendidikan rendah dan hanya bekerja berdasarkan suruhan atasannya yang justru atasan yang seharusnya bertanggungjawab namun sama sekali tidak terjamah oleh hukum pidana. Padahal secara konsep dimungkinkan hal tersebut.

Perekonomian Indonesia tentu akan banyak memberikan manfaat kepada keuangan negara dengan penegakan Pidana terhadap korporasi yang banyak melakukan tindakan merugikan keuangan Negara dengan menjarah kekayaan alam Indonesia secara massif yang seharusnya kekayaan alam itu adalah untuk masyarakat, sehingga sebenarnya akan mampu menaikkan kesejahteraan masyarakat Indonesia secara keseluruhan, namun dengan merajalelanya kejahatan korporasi yang tidak bisa ditindak secara langsung korporasinya, tentu saja hal ini menimbulkan isu menarik yang akandibahas dalam artikel adalah bagaimana reformulasi konstruksi pidana dalam menjerat pelaku tindak pidana korporasi.

\section{B. Metode Penelitian}

Penelitian ini termasuk dalam jenis penelitian normatif.Dalam hal ini sifat penelitian adalah eksploratif, dengan bentuk penelitian preskriptif karena di dalam penelitian hukum tidak diperlukan hipotesis dan tidak dikenal data.(Peter Mahmud Marzuki. 2011: 59-60) Penelitian ini menggunakan pendekatan perundang-undangan (statute approach) dan pendekatan kasus (case approach). Pendekatan Undang-Undang(statute approach) dilakukan dengan menelaah semua Undang-Undang dan regulasi yang bersangkut paut dengan isu hukum yang sedang ditangani. 


\section{Hasil Penelitian dan Pembahasan}

Istilah perbuatan korporasi sebagai kejahatan korporasi digunakan dalam berbagai konteks maupun penamaan. J.E. Sahetapy memberikan catatan penting bahwa istilah kejahatan korporasi (corporate crime) seringkali digunakan untuk menggambarkan konsep white-collar crime, organizational crime, organized crime, georganiseerde misdaad, groepscriminaliteit, misdaad onderneming, crimes of bussiness (bussiness crime), syndicate crime.(J. E. Sahetapy. 2002:1)

David O. Friedrichs sebagaimana dikutip dalam Mahrus Ali mendefenisikan kejahatan korporasi.Gary Slapper dan Steve Tombs, . 1999:16) sebagai: offences committed by corporate officials for their corporation or offences of the corporation itself, yang berarti: tindak pidana yang dilakukan oleh pengurus korporasi untuk kepentingan korporasi atau tindak pidana yang dilakukan oleh korporasi itu sendiri.(Mahrus Ali, 2013: 9)

Marshaal B. Clinaard dan Peter C. Yeager sebagaimana dikutip dalam Setiyono memberikan pengertian kejahatan korporasi sebagai: any act committed by corporation that is punished by the state, regardless of whether it is punished under administrative, civil, or criminal law, yang artinya: setiap tindakan yang dilakukan oleh korporasi yang bisa diberi hukuman oleh negara, entah di bawah hukum administrasi negara, hukum perdata maupun hukum pidana.(Setiyono. 2005: 20)

Ciri khas yang dapat ditemui dari kejahatan korporasi adalah bahwa ia dilakukan oleh korporasi atau pengurusnya (baik pemilik, manager, atau karyawan) untuk kepentingan korporasi itu sendiri, dan secara langsung maupun tidak langsung telah mendatangkankerugian terhadap para stakeholder, yang menurut Etty Utju R.K. dengan mengutip pendapat Muladi, terdiri atas:(Etty Utju R. Koesoemahatmadja. 2011: 6)

a. Negara (state), sebagai akibat kejahatan korporasi, seperti informasi palsu terhadap instansi pemerintah, korupsi, tindak pidana ekonomi, tindak pidana subversi, dan lain-lain.

b. Masyarakat (public), sebagai akibat pencemaran dan perusakan lingkungan hidup, penggelapan, penghindaran pajak, dan lain-lain.

c. Konsumen (consumers), sebagai akibat advertensi yang menyesatkan, menciptakan hasil produksi yang beracun dan berbahaya, dan lain-lain.

d. Karyawan (employees), sebagai akibat kejahatan korporasi berupa lingkungan kerja yang tidak sehat dan tidak aman, pengekangan hak untuk membentuk organisasi buruh, tidak dipenuhinya upah minimum dan lain-lain.

e. Pemegang saham (shareholders/investor), sebagai akibat penipuan dan pemalsuan akuntansi, dan lain-lain.

f. Perusahaan saingan (competitors), sebagai akibat kejahatan spionase industri yang melanggar.

Konsepsi ini membuat istilah kejahatan korporasi (corporate crime) sama sekali berbeda dengan crime against corporation dan criminal corporation. Konsep crime against corporation atau yang biasa disebut kejahatan jabatan atau kejahatan terhadap korporasi, merupakan kejahatan di mana pelaku kejahatan tersebut melakukan kejahatan yang ditujukan kepada korporasi.

Pelaku kejahatan ini tak hanya terbatas karyawan dari badan hukum atau korporasi yang bersangkutan, tapi juga masyarakat secara luas bisa menjadi pelaku kejahatan korporasi 
jenis ini. Sedangkan criminal corporation merupakan padanan lain kejahatan sindikat. Ia diartikan sebagai korporasi yang sengaja dibentuk dan dikendalikan untuk melakukan kejahatan, dengan kata lain kedudukan korporasi hanyalah sebagai sarana melakukan kejahatan.

Sebagaimana telah diuraikan sebelumnya, bahwa kejahatan korporasi menimbulkan kerugian lebih besar jika dibandingkan dengan kejahatan individual atau sering disebut juga sebagai kejahatan konvensional/tradisional. Hal ini diakibatkan oleh karakteristik kejahatan korporasi itu sendiri, antara lain:(Setiyono. 2002: 54-55)

a. Kejahatan tersebut sulit dilihat (low visibility), karena biasanya tertutup oleh kegiatan pekerjaan yang normal dan rutin, melibatkan keahlian profesional dan sistem organisasi yang kompleks;

b. Kejahatan tersebut sangat kompleks (complexity) karena selalu berkaitan dengan kebohongan, penipuan dan pencurian serta seringkali berkaitan dengan sebuah yang ilmiah, teknologis, finansial, legal, terorganisasikan, dan melibatkan banyak orang serta berjalan bertahun-tahun;

c. Terjadinya penyebaran tanggung jawab (diffusion of resposibility), yang semakin luas akibat kompleksitas organisasi;

d. Penyebaran korban yang sangat luas (diffusion of victimization), seperti polusi dan penipuan;

e. Hambatan dalam pendeteksian dan penuntutan (detection and prosecution), sebagai akibat profesionalisme yang tidak seimbang antara aparat penegak hukum dengan pelaku kejahatan.

f. Peraturan yang tidak jelas (ambiguitas law) yang sering menimbulkan kerugian dalam penegakan hukum; dan

g. Sikap mendua status pelaku tindak pidana. Dalam hal perbuatannya tidak melanggar peraturan perundang-undangan, tetapi apa yang dilakukan memang merupakan perbuatan yang ilegal.

Kekhususan kejahatan korporasi yang lazim disebut kejahatan kerah putih adalah pada wilayah kerjanya yang meliputi bidang keuangan dan industri, di mana kerugian yang ditimbulkan dari kejahatan tersebut tidak begitu nyata, kesalahan pelaku tidak begitu jelas, dan perbuatan pelaku tidak bertentangan dengan moral. Hal ini tentu bertentangan dengan konsep kejahatan jalanan (street crimes) yang dengan mudah dapat diidentifikasi, seperti pembunuhan, penganiayaan, pemerkosaan, perampokan, atau pencurian. Kejahatan jalanan umumnya juga melibatkan penggunaan ancaman dan penggunaan kekerasan secara fisik terhadap korban atau pencurian dengan menggunakan kekerasan serta kejahatan-kejahatan lain yang berhubungan dengan hal itu.

Lebih lanjut Simpson mengemukakan ada tiga hal yang patut dicermati dalam kejahatan korporasi. Pertama, bahwa perbuatan ilegal yang dilakukan korporasi dan agennya berbeda dengan yang dilakukan mereka yang memiliki status ekonomi yang lebih rendah, yang semakin menunjukkan perbedaan kejahatan korporasi dengan kejahatan konvensional lainnya. Kedua, baik korporasi dan representasinya dikenali sebagai pelaku. Ketiga, motivasi utama dari suatu kejahatan korporasi adalah bukan untuk kepentingan individu, namun untuk kepentingan korporasi. Oleh karena itu untuk menjaga keuntungan, mengatur suatu pasar, menurunkan biaya perusahaan, atau untuk menyingkirkansaingan dalam dunia usaha, korporasi mungkin 
saja mencemari lingkungan, melakukan penipuan dan manipulasi, menciptakan kondisi kerja yang berbahaya dan lainnya. Kebijakan managerial untuk melakukan tindakan terlarang tersebut dapat dibantu dengan norma dalam korporasi dan subkultur korporasi.

Pada awalnya korporasi atau badan hukum (rechtpersoon) adalah subjek yang hanya dikenal di dalam hukum perdata. Apa yang dinamakan badan hukum itu sebenarnya adalah ciptaan hukum, yaitu dengan menunjuk kepada adanya suatu badan yang diberi status sebagai subjek hukum, di samping subjek hukum yang berwujud manusia alamiah (natuurlijk persoon), dengan berjalannya waktu, pesatnya pertumbuhan ekonomi dunia yang mengarah ke globalisasi di mana memberikan peluang yang besar akan tumbuhnya perusahaan-perusahaan transnasional, maka peran dari korporasi makin sering kita rasakan bahkan banyak memengaruhi sektor-sektor kehidupan manusia dan dampak yang kita rasakan menurut sifatnya ada dua yaitu dampak positif dan dampak negatif. untuk yang berdampak positif, kita sependapat bahwa itu tidak menjadi masalah namun yang berdampak negatif inilah yang saat ini sering kita rasakan.

Kitab Undang-Undang Hukum Pidana (KUHP) sebagai dasar hukum pemidanaan atas perkara-perkara pidana umum, hanya mengatur subyek hukum hanya manusia sebagai pendukung hak dan kewajiban. Dalam rumusan pasal-pasal di dalam KUHP, tidak mencantumkan subyek hukum yang dapat dikenakan selain manusia atau terhadap korporasi. Pada waktu dirumuskan, penyusun KUHP menerima asas universitas delinquere non protest, yang artinya korporasi tidak mungkin melakukan tindak pidana, sebab korporasi dipandang sebagai suatu fiksi hukum dalam lingkungan keperdataan yang tidak cocok diambil alih dalam hukum pidana.

Di negara-negara Common Law System seperti Amerika, Inggris, dan Kanada upaya untuk membebankan pertanggungjawaban pidana korporasi (corporate criminal liability) sudah dilakukan pada saat Revolusi Industri, menurut Remy Sjahdeini ada dua ajaran pokok yang menjadi pembenaran dibebankannya pertanggungjawaban pidana kepada korporasi. Ajaran-ajaran tersebut adalah doctrine of strict liability dan doctrine of vicarious liability.

Pencantuman korporasi sebagai subyek hukum menunjukkan bahwa Indonesia mulai mengadopsi adanya pertanggungjawaban pidana terhadap korporasi dan sudah mengakui bahwa subyek hukum bukan hanya manusia saja tetapi juga korporasi.Hingga saat ini, masih terdapat ketidakseragaman proses penegakan hukum terhadap korporasi di pelbagai negara, bahkan di salah satu negara di Eropa yaitu Jerman, sampai saat ini tidak mengenal adanya pertanggungjawaban pidana yang dikenakan terhadap korporasi, sebab Jerman masih menganut paham bahwa yang dibebani pertanggungjawaban adalah orang per orang dan korporasi tidak dapat dibebani pertanggungjawaban pidana. Meski demikian, dalam praktik, di berbagai negara lainnya, seperti Belanda ataupun Prancis, telah menerapkan pertanggungjawaban pidana kepada korporasi.

Indonesia sebagai negara yang menganut sistem hukum Eropa Kontinental (civil law) yang merupakan sistem hukum warisan dari Belanda, telah pula menerapkan sistem pertanggungjawaban pidana terhadap korporasi. Akan tetapi, meskipun Indonesia telah menganut sistem pertanggungjawaban pidana terhadap korporasi, hingga saat ini masih sedikit korporasi yang dijadikan tersangka atau terdakwa dalam proses penegakan hukum terhadap korporasi. 
Dalam sejarah perkembangan pertanggungjawaban pidana terhadap korporasi, bisa dibagi menjadi :

a) Pengurus korporasi yang dijadikan tersangka atau terdakwa, yaitu ketika pertanggungjawaban pidana terhadap korporasi hanya dibebankan kepada pengurus korporasi dan bukan kepada korporasi yang bersangkutan ;

b) Korporasi yang dijadikan tersangka atau terdakwa, yaitu ketika pertanggungjawaban pidana terhadap korporasi hanya dibebankan kepada korporasi dan tidak dibebankan kepada prngurus korporasi ;

c) Pengurus korporasi dan korporasi secara bersama-sama dijadikan tersangka atau terdakwa, yaitu ketika pertanggungjawaban pidana terhadap korporasi dibebankan secara bersama-sama kepada pengurus dan korporasi yang bersangkutan.

Apabila kita melihat pada proses penegakan hukum atas pertanggungjawaban pidana terhadap korporasi, maka dapat dijabarkan secara singkat sebagai berikut :

a) Pengurus diajukan terlebih dahulu sebagai tersangka atau terdakwa dan setelah pengurus tersebut sebagai terdakwa telah dijatuhi putusan pemidanaan, kemudian korporasi diajukan sebagai tersangka atau terdakwa;

b) Korporasi diajukan terlebih dahulu sebagai tersangka atau terdakwa dan setelah korporasi tersebut sebagai terdakwa telah dijatuhi putusan pemidanaan, kemudian pengurus diajukan sebagai tersangka atau terdakwa ;

c) Korporasi dan pengurus diajukan secara bersama-sama sebagai tersangka atau terdakwa;

Dari ketiga proses penegakan hukum terhadap pertanggungjawaban pidana korporasi, terhadap pengajuan pengurus maupun korporasi secara terpisah, baik pengurus yang diajukan terlebih dahulu maupun korporasi yang diajukan terlebih dahulu, mengandung kelemahan yaitu ketika pada tahap penjatuhan pemidanaan dan putusan pemidanaan sudah mempunyai kekuatan hukum tetap (inkracht van gewijsde) tentu akan membutuhkan waktu yang lama, bahkan mungkin sampai bertahun-tahun perkara a quo baru mempunyai kekuatan hukum tetap. Hal ini menyebabkan akan terjadi kesulitan dalam proses pengajuan pihak berikutnya dalam proses penegakan hukum, mengingat dengan jangka waktu yang lama bisa menyebabkan rusak atau hilangnya barang bukti, menghilangnya korporasi karena terjadi peleburan, pembubaran dan sebab-sebab lainnya.

Sedangkan apabila korporasi dan pengurus diajukan secara bersama-sama dan dalam waktu yang sama sebagai tersangka maupun terdakwa, maka akan memudahkan proses pemeriksaan perkara pada tiap tingkatan proses penegakan hukum. Di samping itu, khusus pada tahap persidangan, tentu akan membuat persidangan dapat dilakukansecara cepat dan biaya ringan serta proses rehabilitasi maupun ganti rugi kepada pihak-pihak yang dirugikan dapat cepat dilakukan.

Perkembangan hukum di Indonesia, menuntut agar korporasi juga dapat dijadikan sebagai subyek hukum. Hal ini didasarkan pada prinsip hukum yaitu dalam prinsip hukum terdapat dua subjek hukum, yaitu subjek hukum orang/manusia dan subjek hukum korporasi, yaitu Orang (persoon) berarti pembawa hak atau subyek di dalam hukum, di mana seseorang dikatakan sebagai subjek hukum (pembawa hak), dimulai dari ia dilahirkan dan berakhir saat ia meninggal dan selain orang badan-badan hukum atau perkumpulan-perkumpulan juga memiliki hak dan dapat melakukan perbuatan hukum seperti seorang manusia, sebab badan-badan atau perkumpulan-perkumpulan itu mempunyai kekayaan sendiri, ikut serta 
dalam kegiatan praktek hukum dengan perantara pengurusnya, dapat digugat, dan dapat juga menggugat di muka hakim, oleh karena itu, intinya posisi badan hukum juga dibebani dengan hak dan kewajiban hukum yang sama dimiliki oleh subjek hukum orang/manusia.

Dalam perundang-undangan di Indonesia, sudah mengakomodir korporasi, baik yang berbentuk badan hukum maupun non badan hukum dijadikan subyek hukum, yangjuga mendukung hak dan kewajiban yang sama sebagaimana yang dimiliki oleh manusia. Hal ini terlihat pada Undang-Undang Nomor 21 Tahun 2007 tentang Pemberantasan Tindak Pidana Perdagangan Orang, Undang-Undang Nomor 20 Tahun 2011 tentang Pemberantasan Tindak Pidana Korupsi, Undang-Undang Nomor 32 Tahun 2009 tentang Perlindungan dan Pengelolaan Lingkungan Hidup, Undang-Undang Nomor 40 Tahun 2007 tentang Perseroan Terbatas, Undang-undang No. 8 Tahun 2011 Tentang Pencegahan dan Pemberantasan Tindak Pidana Pencucian Uang. dan beberapa peraturan perundang-undangan yang lain.

Hingga saat ini, di Indonesia, telah ada sekitar 100 produk perundang-undangan yang menyebutkan korporasi sebagai subyek hukum, sebagai pendukung hak dan kewajiban sebagaimana manusia juga sebagai subyek hukum. Oleh karena itu, yang dibutuhkan saat ini adalah keberanian dari Aparat Penegak Hukum (APH) untuk mengajukan korporasi, baik yang yang berbadan hukum maupun yang tidak berbadan hukum sebagai tersangka ataupun sebagai terdakwa apabila korporasi tersebut melakukan tindak pidana.

\section{Simpulan}

Korporasi sebagai subjek tindak pidana perumusannya berada dalam peraturan perundang-undangan di luar KUHP, suatu tindak pidana dikatakan dapat dilakukan oleh korporasi apabila berdasarkan hubungan kerja atau hubungan lain, dan dalam lingkungan korporasi. Maka langkah selanjutnya dalam membebankan pertanggungjawaban pidana kepada korporasi adalah dengan menentukan aturan atau syarat mengenai kapan suatu korporasi dikatakan melakukan tindak pidana.

\section{E. Saran/Rekomendasi}

Penegak Hukum dalam hal ini Jaksa Penuntut Umum hendaknya dapat membedakan jenis pidana yang dapat diterapkan kepada orang dan jenis-jenis pidana yang dapat diterapkan kepada korporasi, agar supaya korporasi yang melakukan tindak pidana dapat dijatuhi pidana sesuai dengan kapasitasnya sebagai subjek tindak pidana bukan orang

\section{F. Daftar Pustaka}

Barda Nawawi Arief. 200. Kapita Selekta Hukum Pidana, Bandung: Citra Aditya Bakti. 2007. Masalah Penegakan Hukum dan Kebijakan Hukum Pidana dalam Penanggulangan Kejahatan, Jakarta: Kencana Prenada Group.

Etty Utju R. Koesoemahatmadja. 2011. Hukum Korporasi Penegakan Hukum terhadap Pelaku Economic Crimes dan Perlindungan Abuse of Power, Jakarta: Ghalia Indonesia. 
Gary Slapper dan Steve Tombs. 1999. Corporate Crime. London:Longman.

J. E. Sahetapy. 2002. Kejahatan Korporasi, Cetakan Kedua. Bandung: PT. Refika Aditama.

Lisa H. Nicholson.2007. "The Culture of Under-Enforcement: Buried Treasure, Sarbanes-Oxley and the Corporate Pirate", DePaul Business \& Commercial Law Journal.

Mahrus Ali, 2013. Asas-asas Hukum Pidana Korporasi.Cetakan Pertama, Jakarta:Raja GrafindoPersada.

Mudzakkir. Dkk. 2010.Perencanaan Pembangunan Hukum Nasional BidangHukum Pidana dan Sistem Pemidanaan (Politik Hukum dan Pemidanaan), Jakarta:Badan PembinaanHukum Nasional Kementrian Hukum dan Hak Asasi Manusia.

Muh Fityatul Kahfi. 2016. “Tinjauan Normatif Terhadap Pertanggungjawaban Pidana Korporasi Dalam Tindak Pidana Perikanan”.Skripsi, Makassar:Universitas Hasanudin.

Nyoman Serikat Putra Jaya, 2005. Relevansi Hukum Pidana Adat dalam Pembaruan Hukum PidanaNasional, Bandung: Citra Aditya Bakti.

Peter Mahmud Marzuki. 2011. Penelitian Hukum, Jakarta:Kencana.

Rufinus Hotmaulana Hutauruk. 2008. Penanggulangan Kejahatan Korporasi; Suatu Terobosan, Cetakan Pertama, Jakarta:Gramedia.

Setiyono. 2002.Analisis Viktimologis dan Pertanggungjawaban Korporasi Dalam Hukum Pidana Indonesia, Malang:Averros Press.

2005. Kejahatan Korporasi, Cetakan Ketiga, Malang:Bayumedia Publishing

Teguh Soedarsono, “Penegakan Hukum dan Putusan Peradilan Kasus-kasus Illegal Logging”, Jurnal Hukum LPSK, Jakarta, 2010.

Yesmil Anwar dan Adang. 2008. Pembaruan Hukum Pidana, Reformasi Hukum Pidana, Jakarta:Grasindo.

http://pn-tilamuta.go.id/2016/05/23/penerapan-pertanggungjawaban-korporasi-dalam-hukumpidana/, diakses tanggal 25 Nopember 2017 pada 21:22 WIB.

http://www.hukumpedia.com/ndrausumayudha21/memperjelas-tanggung-jawab-hukumkorporasi-sebagai-subjek-hukum-sebuah-kajian-hukum-dalam-menghadapi-masyarakatekonomi-asean-mea, diakses tanggal 25 Nopember 2017 pada 21:28 WIB.

http://via.library.depaul.edu/cgi/viewcontent.cgi?article $=1174 \&$ context $=$ bclj, diakses pada tanggal 6 Nopember 2017 